\title{
GLOBALIZATION AND VALUES
}

\author{
JOHN WHALLEY
}

\section{CESIFO WORKING PAPER No. 1441}

CATEgORY 7: TRADE POLICY

APRIL 2005

Presented at CESifo Venice Summer Institute, Workshop on

DisSECTING GLOBALIZATION, July 2004

An electronic version of the paper may be downloaded

- from the SSRN website: Www.SSRN.com

- from the CESifo website: www.CESifo.de 


\title{
GLOBALIZATION AND VALUES
}

\begin{abstract}
This paper discusses a central element in globalization debate little addressed by economists, namely the interactions at global, national, and community levels between globalization and societally based values. Social values refer to wider notions of collective identity: religious values, attitudes towards materialism, moral beliefs, and a sense of collective awareness and are a broader and more encompassing concept than social capital discussed in recent economics and sociology literature. Social capital relates to trust, honesty and the social fabric of accepted norms central to the successful implementation of individual optimizing decisions, and denotes a communal asset reflecting strength of joint collective commitment whose amount can be increased or improved upon through investment of time and resources. Social values are much discussed in sociological literature going back to Comte, Durkheim, Parsons, and others. The issues taken up here are how different social values might interact and change as societies and their economies integrate (globalize). Processes of value competition, displacement, joint assimilation occur naturally to economists, but seem little studied by sociologists who seemingly place less stress on analytical comparative statics. Scenarios for how values can interact under globalization are discussed in the text.
\end{abstract}

JEL Code: F00, F02, Z1, Z13.

\author{
John Whalley \\ Department of Economics \\ University of Western Ontario \\ London, Ontario, N6A 5C2 \\ Canada \\ jwhalley@uwo.ca
}

This paper was presented at a CESIFO area group meeting held in Munich, Jan. 29/30 2004. An earlier version was presented at CSGR (Warwick). I am grateful to Robin Cohen, Sian Sullivan, Marc Muendler, Syed Ahsan, Ray Riesman, Hans Werner Sinn, and James Brassett and seminar participants for comments. It draws on discussions with Jan Aart Schoelte, Richard Higgott, Andrew Cooper, and Bob Young. I am grateful to Edgar Cudmore, Maniche Pandey and Josh Svatek for research support. 


\section{Introduction}

This paper discusses how globalization processes can affect social values and vice versa. It takes as its notion of values communally shared beliefs (such as rankings of considerations in defining social arrangements such as responsibility and freedom, order and liberty, religious beliefs, attitudes towards materialism, attitudes towards the natural environment, communal identification). Accepting that values differ between both societies and economies, I treat social values as providing a broad framework within which economies operate as a part of a linked social system. I consider values as a system of jointly accepted constraints on individual behaviour in the tradition of Parsons (1937), and as the central defining entity of what we understand by the term society. I then examine how globalization viewed in its economic dimensions as ever deeper market based integration can influence values and how values can influence the impacts of globalization.

I suggest that the main focus of literature on social values in disciplines outside of economics (sociology, political science) has been to describe, classify, and rationalize alternative conceptualizations of both society and communally accepted value systems. The discussion is of the historical evolution of societies; whether social structures can be adequately represented by equilibrium processes (or whether conflict and discrete change is the norm); whether collectively held values are consistent with individual rationality; and what descriptions of values systems best represent different social entities (communities, nations, families, civilizations). These discussions occur along with various speculations and arguments as to how value systems may evolve in the future given historical patterns from the past. 
In broader globalization debate how a more globalized world both changes and interacts with nationally based value systems in a central issue. My objective here is narrower, namely to discuss possible interactions between social values and globalization shocks from viewpoints that seem natural to economists who work with analytical structures that can be used for comparative static analyses. Accepting that different value systems occur in different societies, I ask how they can jointly interact, change, and adapt when societies are subjected to various shocks associated with globalization, such as deeper market integration, increased speed of transactions across societies, more rapid technical progress, economic marginalization within and between societies and other globally driven forces for changes. Can the values of one society come to dominate or subsume those of another if, say, market based integration occurs across two or more economies?

And if economies are only part of wider social systems, what form of interconnection / interpenetration of values inevitably occurs if market driven globalization occurs? Can value systems blend one with another under the influence of market based globalization, assimilating features of each? Can values of weaker societies effectively become dysfunctional and collapse, and what are the consequences if this happens? What might happen if the values of one society are myopically (or naively) transplanted into another society; and what can be the impact on economic (and wider) social performance? Are the impacts on economic performance of value erosion or strengthening likely to be large or small compared to existing estimates of more conventional economic impacts of market liberalization and integration? How should effects on values be traded off against more conventional economic impacts of policy reform, such as the gains from trade when trade liberalization occurs. 
My aim is to transplant the thinking of economists into other disciplines in ways which other disciplines may find helpful, while at the same time posing issues raised by other disciplines for economists in language closer to theirs. In the process the idea ultimately is to blend analytical techniques from economics into the discussion and language of other disciplines when analyzing the effects of globalization. I suggest that considerable portions of analytical economics literature, such as that on tax competition, policy coordination, currency competition (bimetallism), the design of international institutions and other matters can be drawn on and results from these might suggest how value systems could interact in various circumstances. I discuss what some of the elements of value system interaction could be in global trade policy disputes/clashes, and discuss the relationship of these to Huntington's (1996) characterization of globalization as a clash of civilizations. In some (but not all) cases I also suggest that the indirect channels of globalization's impacts first on social values and as a consequence on economic performance, may be as, if not more, important for evaluating what impacts globalization on economic performance are than the direct effects discussed in more conventional economics literature (such as impacts on consumption, production, and welfare).

The (perhaps unsurprising to some) conclusion is that social values can interact under globalization in complex ways and likely there is no general statement as to what outcomes will be observed since there are many scenarios as to how things might unfold. But if gains (or losses) from globalization go beyond conventional economic impacts such as the gains from trade, and if globalization pressures which modify societal values both for better and for worse are (as I believe) central to the globalization process, then this may be an area also worthy of other economists attention. These conclusions may not 
seem insightful for analytical economists seeking clean general statements from formalized analytical models allowing deductive logic to be carefully applied, but value system interaction is frequently raised as a potentially important area of impact for globalization driven change, and the relative lack of discussion by economists of these issues motivates the discussions here. 


\section{Social Values and Social Capital}

For the purposes of the current discussion, I use the term social values in the sense of Parsons (1937) as relating to shared beliefs within a group of individuals living in a society which have the effect of constraining and partially determining individual behaviour. These may be religious beliefs, attitudes to materialism and property in general, attitudes towards the natural environment, agreements on collective governance, or jointly shared positions on the relative importance of objectives in defining social arrangements. The latter may reflect the relative importance of responsibility and freedom (an Asian/European-North American difference), of between order and good government and individual liberty (a difference between the US Constitution and the British North America Act which shaped Canadian identity.) ${ }^{1}$

Typically social values are not shared in the same way by all members of a society and opinions will differ and conflict will occur over what should be the jointly accepted commitments underlying the value system reflected in constitutional and legal arrangements. For now, I will assume that some system of beliefs can be represented as the jointly agreed values of the collective itself (the nation, if you will).

As such, social values is a considerably broader term than social capital as emphasized in recent literature in economics and sociology (Loury (1977), Coleman

\footnotetext{
${ }^{1}$ The distinctiveness of national character, and hence social value systems is repeatedly stressed in nationalistic literature. For instance, Lin (1935) in his famous discussion of the Chinese character (p. 57) remarks " ...the Chinese are a hard-boiled lot. There is no nonsense about them; they do not live in order to die, as the Christians pretend to do, nor do they seek for a Utopia on earth, as many seers of the West do. They just want to order this life on earth, which they know to be full of pain and sorrow, so that they may work peaceably, endure nobily, and live happily. Of the noble virtues of the West, of nobility, ambition, zeal for reform, public spirit, sense for adventure and heroic courage, the Chinese are devoid. They cannot be interested in climbing Mont Blanc or in exploring the North Pole. But they are tremendously interested in this commonplace world, and they have an indomitable patience, an indefatigable industry, a sense of duty, a level-headed commonsense, cheerfulness, humour, tolerance, pacificism, and that unequalled genius for finding happiness in hard environments which we call contentment - qualities that make this commonplace life enjoyable to them. And chief of these are pacificism and tolerance, which are the mark of a mellow culture, and which seem to be lacking in modern Europe.”
} 
(1988), Portes (1998), Manski (2000)). Social capital relates to collective commitment in the form of trust, honesty, and other elements of social arrangements necessary for the execution of individual optimization plans, and is something whose level can be raised by investment of time and resources. Social values define the constraints on behaviour that mutually accepted beliefs imply and can be thought of as reflecting shared beliefs as to how individuals relate to one another in many aspects of their daily lives. Values differ from social capital in providing the framework for communally acceptable individual behaviour within which both societies and economies function. If accepted as determinants of individuals' behaviour they qualify (or add to) the view that individual self interest alone motivates individual behaviour.

In the humanities societal values are taken as embodied in the literature, music, art, architecture and other forms of expression created by a smaller number of members of society as a distinctive representation and manifestation of the collective identity of society itself. Cunningham and Reich (1994) document the emergence of Western societies from prehistory to the present day in these terms, equating the evolution of Western values with the development of Western civilization. Embree (1972) describes a similar process for the emergence of Vedic culture and values in South Asia and neighbouring areas.

Since Parsons, social values have been taken to be important for the many social structures in which individuals simultaneously participate; many of which cross national boundaries (families, religious or ethnic groups, local or regional communities, work, related groups, gender groups, and many more). Whether acceptance of social value based arrangements is in the individual self-interest is an issue discussed in sociological literature on values, as is how and why value systems embodying such implicit 
agreements come about. Economists in their workings tend to focus more on the ways in which societal values (norms) can influence individual behaviour, and less on how they arise. Akerloff (1994) and Liebenstein (1950) are examples. The classical economist most centrally credited with discussion of how societal norms and individual behaviour interact is Veblen (1899), who used the term conspicuous consumption to indicate consumption activity undertaken largely for its effects on an individual's reputation with others.

For the purposes of the discussion here, I will adopt a narrow concept of social values which I adopt specifically for my discussion of links between values and globalization seen in terms of market based integration. I follow Granovetter (1985) and stress that market based economies function in ways that reflect their embedment in wider social structures. Arrangements for private property will differ, mechanisms to protect natural habitat in the presence of market based activities will vary, religious beliefs may limit both the type and form of market transactions, and social conventions will come into play as it is not possible to rely on legal contracts alone to detail what exchange or production activity will actually take place since there are always elements of ambiguity in the execution of all contractual arrangements. Thus, what economists typically characterize as an economy, i.e. a set of individuals (or households) with endowments and preferences in an Arrow-Debreu (1954) pure exchange or with production framework should in reality be placed in a wider social context in which social values play potentially a major role in both facilitating and constraining the market based transactions at the heart of an Arrow-Debreu world. In turn, social values are themselves affected as different market based transactions occur. 
Earlier discussions of the embeddedness of market transactions in social systems can be found in Arrow (1970) and the literature on social capital (Loury (1977), Coleman (1998), Matthews (1996), North (1997), Collier (1998), Portes (1998), Manski (2000) and Durlauf and Fafchamps (2004)), where social capital is taken to refer to communal arrangements that affect individual behaviour (such as the trustworthiness and honesty of others). Social capital, in turn, is something that can be invested in through joint commitment of time and resources. Social capital is thus something which can be added to through investment in joint commitment, and in a de novo world no social capital would exist.

Values in contrast denote the environment into which individuals are born as social animals and live their lives. They reflect shared religious beliefs, attitudes to property, accepted codes of moral conduct and other elements of social arrangements which both constrain individual behaviour and act as shared or collective identity. Their sharing and acceptance is a key part of the socialization process stressed by Parsons, and a de novo world without values is hard to imagine. Children are raised by parents in ways which reflect how as children they were similarly treated. As mature adults they expect to both care for their parents and their own children since this is what they learn from their own parents. Within communities (villages, for instance) members accept that they will help each other in times of stress (bad harvests and weather) since they jointly implicitly agree to coinsurance and experience such arrangements from birth. The commitments reflected in value systems do not involve investment of time and resources, as with social capital (such as the accumulation of trust when implementing transactions as stressed in social capital literature). They exist as part of the social endowment, and they change and 
evolve over time with changed beliefs, perspectives and circumstances, some of which can reflect globalization induced change.

One example how market based arrangements and social values interact reflects the inability in practice of individuals to fully synchronize the timing of all transactions and to fully monitor the quality and reliability of goods transacted upon delivery. Thus, if buyers and sellers of commodities in markets do not accept each other as having shared values, they may suspect that their market partner may not faithfully execute what is agreed between them. If values differ between the transactors, market transactions may be more difficult to execute and overall economic efficiency may suffer.

One might claim on these grounds that market oriented reforms were implemented in Russia after 1991 in part as property right enhancing reforms in the hope they might make reversion to the previous regime of collectivist central planning more difficult and that the outcome in the absence of needed modifications to shared social values to allow for efficient market transactions was economic implosion on a major scale. This precipitated a large fall in income per capita over 7 years in both Russia and most other former Soviet republics (by perhaps 35-50\%), with reversion to inefficient barter trade, extensive tax evasion, and asset stripping in enterprises. Underlying this economic collapse was the delayed value system changes needed to fully support the newly established market arrangements. Growth in Russia since the financial crisis of 1998 could then be taken to represent the eventual evolution of supportive value system change for the market oriented reforms of 1991. This explanation also raises the issue of whether slower and more successful policy change in China reflected realism as to the initial smaller value system modification. 
The contention I make for the purposes of this paper is that for their efficient functioning market based economies in reality need a supportive system of reasonably widely shared social values which provide a fair degree of certainty to market transactors of the behaviour they will encounter from others. If value systems become less supportive of markets or new market arrangements need changes in value based arrangements for their successful implementation, economic transactions can take more time with more resources devoted to verify completion of agreed contracts. Individuals find ex post mechanisms to resolve disputes (returning goods, receiving refunds, etc) less satisfactory, and weakened social values impair market based economic performance.

At the same time, the social values that perform this role can themselves be affected by changed market activity and in ways which affect both collective identity and how individuals see their own participation in the wider social structure. This may be in ways which are either beneficial or retrograde. Growth, for instance, may lead to more dynamism and confidence in the future which might strengthen supportive value system arrangements. But if economic growth reinforces a sense of collective identity which is seen as excessively materially oriented and neglectful of people in their own right over property and possessions, such changes in values might alternatively be viewed as retrograde. $^{2}$

\footnotetext{
${ }^{2}$ See recent literature in economic psychology (Kasser and Kasser (2001) and Kasser and Kanner (2004)) which reports on research showing that when people rate the relative importance of materialistic values highly compared to other values such as self acceptance, community belonging, and interpersonal relationships, a lower quality of life is also reported. For instance, in clinical studies mature adolescents with stronger materialistic motivation report lower vitality, as well as more depression and anxiety.
} 


\section{Social Thought and Social Values}

The literature on social thought does not discuss social value in quite the same ways as I do above, but it does build centrally on the notion that there is a distinct entity which one can term society, and that (at least in older thought) this can both be studied objectively and its jointly shared values both constrain and partly determine individual actions. Sociologists over the years have devoted much energy to discussing society and its associated value systems in these terms, and I perhaps do this literature poor justice in the ways I bring it into my discussion here.

Sociological theories of society are often traced to the enlightenment and to Auguste Comte whose ideas were formed during the French Revolution, and the political and social instability which followed involving republican governments, monarchy, and Napoleonic empire. Comte's objective was to develop a vision for France of a better society which he hoped would take France out of its instability and provide social progress for all. He saw society as an organism progressively evolving from simple to more complex forms, and he tried to uncover rules that governed both the structure and evolution of social interactions. In so doing, he studied the implicit rules and institutions which organize society as a whole, separate from the direct interests of the individuals who live in the social structure. He tried to explain how social structures come about and analyze how individual self-interest can best be restrained by social conventions so that social stability ensues. He emphasized the role of family, government, and religion in the emergence and operation of social value systems.

Subsequent $19^{\text {th }}$ century writers further developed the same notion that society is an entity shaping and constraining individual behaviour that exists beyond the individual interests of its participants. This included thinkers that modern day economists think of 
as analyzing largely only individualistic behaviour, such as Marshall and Pareto (both of whose views on these matters are discussed at length along with Durkheim and Weber as founders of modern sociology by Parsons (1937)). Thus Marx (see Avineri (1978)) developed a class based framework for looking at society, with individuals (or households) seen as members of classes and history as largely reflecting the outcome of class struggles. Later, Durkheim (1933) analyzed modern society as evolving from segmented traditional structures to more formally organized entities with laws and supporting institutions. His study of society (in Siedman’s (2004) words) was of “shared institutions, cultural beliefs, and social conventions that are irreducible to individual psychology.” Weber $(1951,1957)$ studied the social value systems of Western Europe and China, seeking in part to explain why religious value systems in Europe had generated the Industrial Revolution, and why this same outcome had not occurred in Imperial China.

$20^{\text {th }}$ Century writers developed more complex conceptualisations of both society and its associated value systems. Parsons (1933) saw the actions of individuals within any social structure as determined both by individually based choice and jointly accepted constraints on these choices, with these constraints determined simultaneously along with the precise form of the social structure itself. Parsons explicitly rejected notions of individual self interest is reflecting Darwinian natural selection and survival (genetic determinism) and accounting for the evolution of social structure as appears in contemporary socio-biology literature (see Dawkins (1997) and Wilson (1975)). Instead social order arose from a process of social coordination and cultural consensus. In this, the needs and motivations of the individual and the role requirements of the social entity fitted each other. Social disorder arose from allocative conflict; divisions over who gets 
what. Disruption of social order was inevitable as societies were subject to external shocks. If social order broke down all together, the coercive force of the state (police, military, law) might be resorted to so as to restore social order.

In Parsons’ approach to society, individuals are seen as having both identification with and a sense of joint ownership in society as a whole. Individuals are attached to class, ethnic, racial and other groupings, and in modern states also to national communities; communities of national citizens. Parsons did not discuss global identity, and how a process of globalization might eventually fuse separate national identities into a combined and multifaceted global identity. Nor is there any discussion of how societies and social values may cross national borders in ways which no longer overlap with nation states. The Parsonian view of the world centred on societies as nation states.

Later sociological literature contains many elaborations on this theme as well as challenges to its central notions. Berger and Luckmann (1967), for instance, further developed Parsons' ideas by asserting an objective reality for society which they saw (again in Siedman's (2004) words) as “part of a more encompassing supra-human order of nature or the divine. Social institutions are granted authority not by mere human but by divine decree, natural law, or historical destiny. Religion, philosophy, myth, and science have been the chief symbolic strategies of social legitimation. They re-establish everyday perceptions of the social world as an objective order that can ground our subjective experience as orderly, coherent, and purposeful.”

Subsequent writers, such as Blau (1975) and Collins (1986) advanced what they portrayed as a scientific theory of social structure. Collins saw all human beings as “sociably conflict-prone animals". Blau explained how social order prevailed using a theory of social structure reflecting distributions of individuals across a range of social 
metrics (gender, age, race, income), some of which were discrete (race) and others continuous (income).

Other literature fundamentally challenges the Parsonian view of society. Conflict theory, as advanced by Dahrendorf (1959), suggests that role structures within society inevitably generate conflict and hence societies continually change and evolve; ideas taken further in a widely cited reformulation and extension of Parson's ideas by Giddens (1973) captured in the term structuralism. Related notions of symbolic interactionism were developed by Blumer (1969) and Roch (1979) as a new societal construct, as were phenomenological sociology and ethnomethodology by Garfinkel (1967) and Girourel (1973).

In recent literature on globalization, Beck (1997) focuses on the need to understand what he calls a "world risk society”, looking at ecological and technological risk, and their social and political implications. This forms the basis for Beck's call for a ‘Cosmopolitan Manifesto' to address the joint-evolution of global and local communities responding to issues which national politics cannot adequately address.

Wallerstein (2001) emphasizes the need to re (or, un)think the paradigms of $19^{\text {th }}$ century social thought that limit discussion of the ways in which contemporary processes such as globalization can be dealt with at a societal level. Wallerstein's world-systems analysis is less a theory of the social structures of the modern world than a critique of how he sees scientific social enquiry being undertaken. Castells (2004), in an influential 3 volume piece tries to account for the complex intertwinings of progressive and reactionary forces underpinning globalization and its related forces, which he sees as changing our current world. The objectives of anti globalization movements are analyzed in this work, along with associated economic and political implications. 
For the purposes of my discussion here, I simply take all of this literature as supporting the claim that individuals do indeed have collective identity and this is part of the system of social values. Both this collective identity and other elements of the system of social values both constrain and influence individual behaviour in ways which go beyond narrowly conceived individual self interest.

If this is accepted, then concern both over how values affect behaviour, and changed market behaviour can change values become part of discussion of the effects of globalization, including analyses undertaken by economists. Understanding how collective identity enters individual decision making may be necessary to make realistic assessments of the impacts of globalization on economic performance; and market based globalization itself may have important implications for values and collective identity. As globalization in the form of market based integration moves forward, the conjecture is that an evolving multifaceted global social value system will evolve. If supportive it will more easily facilitate market based transactions, and if less supportive may retard economic progress. How global value systems change for better or for worse under a globalization (integration) process involving individual nation states is also an issue.

This line of inquiry points in several directions. One is how we evaluate both the positive and negative influences of value system change and adaptation when discussing particular global policy initiatives as elements of globalization, such as trade liberalization. Another is to how the process of value system change under globalization shocks can be analyzed; does it necessarily lead to improved societal performance or can value system displacement be harmful? Yet another (and even more difficult) task is to quantify such effects. These and other questions are taken up in the next sections which 
discuss how economic literature might be brought to bear in thinking through ways in which globalization shocks and socially based value systems might jointly evolve. 


\section{The Globalization Process as External Shocks Affecting Value}

\section{$\underline{\text { Systems }}$}

Globalization debate often seems to revolve around a set of repeatedly asked but ill defined questions; is globalization good or bad; does it hurt the poor; has it gone too far; should it be stopped, banned, or even imprisoned? Anti globalization literature (Klein (2002), Greider (1997) and others) in turn covers many subareas, including corporatism, branding, outsourcing, financial mania, the impacts on power of multinational companies, and other elements. ${ }^{3}$

The reality as Higgott (2002) points out is that globalization is a contested concept; something we all talk about, have opinions over, are not quite sure what it is. But whatever globalization is, there is little doubt that people are talking about it, and globally. Alan Greenspan, for instance, suggested in a recent speech that WTO trade liberalization should be accelerated to protect globalization, without fully specifying the interest of the Federal Reserve in this matter, what globalization and WTO trade liberalization really were, and why, anyway, globalization was in need of protection.

A central difficulty when discussing globalization is that the term means different things to different disciplines, and even to individual researchers within disciplines. Discussing the effects of globalization on social value systems can thus involve many different discussions with disjoint terminology which can be hard to simultaneously join.

To economists globalization is typically growing trade, ever more foreign investment, increased speed of transactions in financial markets, international diffusion of technology, internationally more mobile labour, and other facets of ever deeper economic

\footnotetext{
${ }^{3}$ Economists have responded to anti globalization arguments in a series of pieces (see Deardorff (2003), and Elliot, Kar, and Richardson (2002), and Segerstrom (2003)) which broadly argue that conventional neoclassical economics gives little support to anti-globalization positions.
} 
integration across national borders. The central element is market based integration as a process in which national barriers to flows of goods, capital, and labour come down and the global economy moves ever closer towards a single globally integrated market economy and away from nationally segmented markets. Along with this goes globally integrated production units, global companies, global branding, and issues of power of corporate entities. With the focus on globalization also come analyses of such issues as the costs of remaining barriers to flows of goods and factors between national economies (especially labour flows, see Hamilton and Whalley (1984)), the effects of more rapid transmission of information and execution of contracts, global product mandates, tax competition, cooperative treaty based arrangements in the face of strategic noncooperative national incentives, macro policy coordination, outsourcing, labour immobility, and other related matters.

To political scientists, globalization suggests global political processes in which there are challenges to national authority structures as mobility across nations accelerates and transfer of nation state functions to supra-national authorities occurs. It leads to evaluation of trans-national political processes, assessments of constraints on the autonomy of national authorities, and even the emergence of partial identification of national citizenry within a new emerging global identity. Analyses of these issues inevitably imply different approaches from those used by economists in their globalization work.

To modern sociologists (following Beck (1997)) globalization is a process of global social interaction, seen as elevating global risk and providing implications for social structures at all levels of interaction (global, national, local). Stress occasioned on local communities by market based integration, and the impact of large adjustments in 
globally more interdependent labour markets in which larger production units (multinationals) dominate provide a major focus, with related concerns over marginalization of smaller, poorer societies and groups within societies. Whether global values can emerge as a fusion of separate national values (if that is possible) is a question which arises, as is what happens to local values as global integration occurs. Yet again, different directions of research are suggested compared to that of other disciplines.

To those with roots in the anti globalization movement (such as Klein (2001)) the key issue is the role played by globalization in elevating corporate concentration and in intensifying global corporate power via outsourcing, branding, and integrated global markets in which goods sell. Antiglobalization protestors also raise issues of the manic behaviour of modern capitalism (Greider (1997) and Strange (1995)); the negative elements of global standardization (McDonaldization as discussed in Ritzer (2000)), the influence of media misrepresentation and portrayal as Glassner (1999) documents, and other issues.

While globalization debate, in reality, encompasses all of the above and more, my point of departure is to ask how should we approach this process from an analytical viewpoint. Can we envisage what processes of value systems adaptation may unfold in certain circumstances, and can we evaluate what elements of the process may be desirable or undesirable? Does globalization (whatever it is) represents a move towards global collective identity with preserved distinctiveness in a global fusion of national values which simultaneously implies global synthesis and conflict among of nationally based social systems? Or is the process where value systems of large entities displace those of the small, and are such processes stable or unstable? 
Clearly, some form of abstraction (and simplification) is needed in such a discussion, and inevitably in the process some of the issues raised in the disciplinary portrayals above cannot be adequately addressed. The dilemma for analytically based researchers is that fully capturing all the links between globalization and social values in a framework which also spans all of the concerns reflected in the current disciplinary foci seems to be beyond reach.

Accepting that market based integrative economic policy components of globalization (such as trade liberalization) need be considered in their wider social context, one can try to analyze some of the consequences using a verbal analytical approach. For this I take this as my position that the central Arrow-Debreu model of general equilibrium that economists use to represent market based economic behaviour (for either an exchange or production economy) should ideally be embedded within wider models of social interaction where social values influence individual behaviour, and also affect the functioning of market based allocative arrangements. ${ }^{4}$ Equally, the effects of market based outcomes on social values need to be captured. A wholism is seemingly needed for models of economic behaviour if they are to have full credibility for those from other disciplines and used to shed light on the impacts of globalization.

A simple example of such an approach (and in the spirit of the new institutional economics) would be that if as a result of globalization shocks trust is less firmly shared between market participants, the time taken to execute transactions may become longer. In this case, the monitoring applied to product quality may be lengthier, and other negative (or positive) effects on economic behaviour from changed value systems

\footnotetext{
${ }^{4}$ There seem to be relatively few models developed by economists which explicitly consider how formalizations of social interactions can be constructed. One which does so is an early piece by Simon (1952) presenting a formal theory of interactions in social groups based on Hormat's (1950) earlier work. See Granovetter (1985) for a more recent discussion.
} 
attributable to globalization could follow. This would suggest that socially embedded models of market interactions could yield different perceptions of the impacts of market driven global integration than models that have no social embedment.

The particular choice of joint economy-wide construct and representation of social value system affects the perceived outcomes of any given policy or other change taken to reflect the process of globalization, but the impacts could be substantial. For example, in a somewhat trivial formalization of a socially embedded model of market behaviour, one could conceive of an economy as having two groups of workers, urban and rural. Labour market transactions involving urban workers selling their labour to urban employers might involve small transactions costs, since these groups already know and trust each other, and similarly for rural workers transacting with rural employers. However, rural workers moving to urban areas might face significantly higher transactions costs (especially in the short run) if trust is not already established between migrating rural workers and urban employers.

Thus, if the desirability of trade liberalization were considered in a traditional small open economy Arrow-Debreu model it would (in the absence of complicating factors such as other distortions, rent shifting, market structure, infant industry considerations) be welfare improving, but if considered in a simple socially embedded structures of this form it could be welfare worsening. Chia and Whalley (1995) report on a numerical model of welfare worsening service trade liberalization using a structure incorporating differential intermediation transactions costs in two countries. Usually the presumption for small open economies is that trade liberalization is a good thing, but Chia and Whalley show that this need not be so in the case for intermediation services and transactions costs, and similar results might apply for a socially embedded model as 
sketched. Another example might be a model with disjoint urban and rural networks with consumption externalities in which average and marginal network values differ. Where differences in average values of networks affect migration between urban and rural areas rather than marginal values, inefficient migration can occur. In this case, much as in Lewis (1954) models of development with traditional practices in the agricultural sector, market based integration (trade liberalization) could be welfare worsening.

Such socially embedded models in either simple or more refined form seem to be little considered by economists since general analytical results are difficult to obtain, and there is a tradition of separation of discussion of economic policy impacts from the social impacts usually verbally discussed in sociological literature. But using numerical simulation methods models incorporating social embedment might produce some of the results sketched out here for certain model parameterizations, which would then be opposite to prevailing economic opinion. An implication would seem to be that the concerns of globalization protesters over market based integration and trade liberalization over negative impacts on social structure, values, and culture could be seen by economists as having more analytic credibility than currently. Using a numerical simulation approach, one might also ask how globalization shocks could impact value systems in some simple socially embedded models, and how the interaction/interpenetration of value systems could in turn provide feedback effects that could also influence the impacts of globalization assessed in more conventional economic terms.

As part of this process one needs to discuss how globalization shocks and their effects might be represented in any such modelling exercises. The idea would be to view globalization as a process of interaction and integration across societies which involves 
changes in both market based arrangements and social value systems. In this process both become enmeshed independently of the type of change occurring. Under this view of the world, economic integration inevitably generates changes in social value systems which then themselves also impact social and economic performance.

Many details would be needed to implement such modelling approaches in concrete instances of interaction, including what are the entities whose value systems are seen as entwined in this way. Is it nation states, sub-national communities, or civilizations as Huntington (1996) suggests? Whichever is chosen (and maybe all need to be considered), analytic models of interaction would need to be accordingly developed. If globalization is viewed in narrower economic terms as movement towards deeper market based integration, one place to begin in analyzing its effects may be to accept that the differing social systems surrounding market activities in national economies also inevitably come into contact as the globalization process moves forwards. A move from, say, autarky to free trade can change the social systems of the countries involved in various ways.

This may involve, say, Chinese trading with Americans relying on social values that characterize the other country's market transactions. In such cases it may be that transactions across social systems are inherently more difficult to execute than those which occur inside socially more homogeneous borders. Maybe these difficulties recede with the passage of time. Maybe the social systems of each entity themselves change in the process and are in some way enriched. Maybe mutual distrust intensifies with unsatisfactory market transactions across social structures. Maybe all of the above occur to some degree. But the hypothesis would be that change of some form (for better or worse) results in social systems from market based globalization which involves moves 
towards deeper economic integration. Similar outcomes could be claimed for other forms of economic globalization, such as increased cross border investment, labour flows, globalization speeded financial market activity, heightened transfer of technology and other processes. Formalizing and eventually quantifying both the social value system consequences of these changes and feedback effects as value systems change and further modify outcomes is the challenge.

In addition, social value system differences clearly influence and may even constrain how economic globalization unfolds as a process. For instance, the limited trade between most African economies and OECD countries is variously ascribed to infrastructural problems in Africa (including civil war), transportation problems, macro economic instability and other factors. But if value systems are so different across social structures that market based transactions between OECD and African economies are inherently more difficult to execute, then evaluating what the key differences in value systems are may offer an approach to speeding market integration and offer a new way of thinking on how to promote more trade. Value system differences might also limit technological diffusion, provide barriers to labour mobility, and have other (to economists) unanticipated effects.

Simply put then, the conjecture I offer is that the process of globalization (whatever it is) influences social value systems (whatever they are), and changes in them (again whatever they are) can influence how globalization plays out as a process in terms of its impacts on economic and social performance indicators. The size and importance of these interactions is for now inevitably only the subject of conjecture since there are sharply competing views of how social structures organize themselves and evolve. Many types of economic models could be built to analyze them, and many elements of 
globalization could be considered in such models. But the effects stemming from interactions between value systems and globalization could be substantial. 


\section{Value System Competition, Collapse, Assimilation, Fusion, and}

\section{$\underline{\text { Conflict }}$}

Analysing the links between social values and globalization requires analytic frameworks to help understand how and why value system changes occur and how globalization shocks to national societies and economies impact societal performance. One approach which could be used is the comparative statics which typifies much post war economic theorizing, as originally set out in Samuelson (1947), Hicks (1939) and in subsequent literature. This approach analyzes what if counterfactuals for hypothetical ex ante change, and goes beyond the tradition of aiming largely to characterize societal structures and the constraints which value systems place on individual behaviour, and assess historical patterns in the evolution of social structures to unearth tendencies for future patterns. To economists it often seems that other disciplines hold back from such analyses perhaps because they are inevitably dependent on assumptions and model structures which themselves are inevitably hypothetical; but without some formal comparative static framework to analyze globalization and value linkage judgements on what is likely or unlikely to occur, or even what are good or bad developments, are difficult to arrive at.

To implement such an approach, one first needs to formalize a joint model of economic behaviour and societal interaction characterized by a joint equilibrium structure. One then can attempt to assess how behaviour in the model chosen would change if various globalization driven shocks to the system occurred, such as policy driven global economic integration or changes in global social arrangements (such as, for instance, new communications technologies.) 
One might, for instance, use comparative statics to ask how social value systems would compete under globalization shocks? Could it be they could partially or wholly assimilate each other, fusing and taking features from each as economic integration occurred? Could there be an outcome in which value systems of smaller social entities were subsumed? Is cooperation between value systems possible in such a structure, such that cooperative outcomes from interactions between value systems with strategic elements could be generated by globalization shocks? And what if the values from one society were to be naively (or myopically) implanted to another, could perverse or unfair outcomes result?

In the process of developing such comparative statics one might ask what types of change in social value systems represent an improvement and which regress, and according to which criteria? And quantitatively, one might assess whether any effects attributed to value system change are likely to be large or small compared to traditional effects of market based integration usually studied by economists, such as the gains from trade.

The model used to capture both social value systems and globalization shocks would be central to such an undertaking. Differential adjustment costs of the type sketched out above might be one simple formulation. Another could be an explicit economic network structure in which preferences of individuals were defined not only over their own consumption, but over the consumption of others. Such a formalization has been recently used by Bhattarai and Whalley (2003) to analyze the effects of global liberalization in network structures in service areas such as telecoms. Applied to social value systems these could be models of disjoint or overlapping networks covering subsets of societies, with a value to each network going beyond the immediate direct benefits of 
consumption of goods to individuals. These are at best sketches of simple, and even rudimentary, formalizations of social value system interactions with economic behaviour but they could provide a starting point for such investigations.

Comparative static exercises using such formalizations could also draw on several strands of recent economic literature depending on the types of globalization shocks considered. These might be models of how jurisdictional policies interact under assimilation, how coordination between national policies might or might not improve things, or how international institutions are best designed given the incentives involved.

The tax competition literature (Wilson (1999)) analyzes possibilities of races to the top or bottom in inter jurisdictional tax rates as mobile factors move between jurisdictions and tax bases expand and contract. International macro policy coordination literature (Obsfeld and Rogoff (1995)) discusses among other things the benefits to joint intervention in multicountry macroeconomic policies and the gains to coordination more generally. Myatt, Shin, and Wallace (2002) and Currie and Levine (1993) provide a more focused discussion of games of coordination in this setting. Recent discussion of international institution arrangements (Stiglitz (2002), and Bagwell and Staiger (1999, 2001, 2003)) focuses on the considerations involved in framing international rules and organizing institutional processes to restrain individual country incentives to depart from globally beneficial arrangements.

How might value systems interact and compete with one another? Suppose two societies one with a high level and one with a low level of trust were to integrate. Would shared or common levels of trust emerge somewhere between the two, or could there be a race to the top (both high levels of trust) or the bottom (both low levels of trust) as transactions moved between the two types of value systems. Likely, as in tax competition 
literature, either outcome may occur but exploring the conditions for one outcome or the other could be informative. Another conjecture might be that much like the role of national currency in the global economy, the persistence of multiple value systems in the long run might not characterize an efficient globality. If values must be shared for common and joint use, then if I connect (or transact) with you my values become yours and yours mine. Just as bimetallism is not viable in the long run as a global specie mechanism, so multiple value systems might not prevail in a long run homogenized globality. Literature on tax competition from Kanbur and Keen (1993), Zodrow and Mieszkowski (1986), could be relevant here; and how value systems (like jurisdictions) interact in either noncooperative Nash form (Wildasin (1988)) or cooperative form (Burbidge et al (1997)) might also be analyzed.

This discussion also presumes that all individuals are to be fully globally connected with all others under globalization, and for all purposes. If subsets of interconnections (transactions) can remain disjoint from each other (either spatially or functionally, or both) then distinct value subsystems might survive. Questions of how common value systems also evolve mirror those surrounding the emergence of common standards for shared technologies. If homogenisation is the trend, which one prevails is an issue; just as with cellphones and VCRs, how a common value standard is determined is key.

Another set of issues is whether in some sense the most efficient value system will prevail under globalization, or whether bad values can drive out good? For example, once corruption is established in an economy can it spread and drive out pro social honest behaviour. Good values (in some sense) may not be able to withstand individual incentives to adopt socially undesirable behaviour (such as corruption) experienced elsewhere. Will social value systems of large entities overpower those of smaller 
entities? This may well be the tendency based on the number of transactions conducted by one or more agents using the larger society’s value system, but the ability of values to change and modify under globalization shocks may differ from society to society.

Can assimilation across value systems occur? Clearly this seems to be both likely and even probably happening to some degree at present. Chinese traders selling in US markets learn US practices and vice versa, and from these experiences they also change their own practices. A global value system might therefore be conceived of as possibly taking the best, in some sense, from all nationally based values to yield a mutated but globally more efficient set of global norms.

Can local collapse in values occur? Where distinctive value systems operate in relatively small and distinct societies, a move to a globalized or socially more widely used value system may result in the submergence and near destruction of local value systems. Traditional societies world wide seemingly bear testimony to these possibilities. Morrisseau (1999), for instance, both documents and discusses the near disintegration of local community based value systems among North American Indian bands in the last two centuries, and the social and individual consequences which result.

What of naive transplantation of values from one society to another? Here clearly undesirable outcomes can occur. Suppose society X collectively sees itself as embodying a value system upheld by the rule of law and protection of individual rights and liberties, and as a large society seeks (even if well intentioned) to transplant its own value system abroad as a form of global social advancement. Suppose that the legal structure in the receiving society is corrupted with bribeable judges, police officers and other elements of a less then legally bound society. Corruption can intensify under such transplantation by an elevation in the role of legal structure in the recipient society. 
In traditional societies with complex informal rights to use, transit, or otherwise employ land, formal systems of land title and registration have been introduced with the purpose of firming up property rights and allowing market trade in land with improved economic efficiency as the objective. The result has been in some cases that informal rights remain as the respected right serving to confuse new legal title, but with new legal title used for the purposes of mortgage access with resulting financial complexity in financial instruments and confusion in title for productive use.

And what of the quantitative consequences of value system interaction of the type speculated on above as occurring along with market driven globalization? Seemingly, where collective identity is a prime and perhaps the key social value, the consequences of social value system changes stemming from globalization can be profound. Morriseau (1999), for instance, documents gas sniffing, drug abuse, teenage pregnancy, and other personally retrograde behaviour in North American Indian Bands attributed to the shared loss from the weakening and near disappearance of collective identity. Morriseau documents how in such cases collective healing is the route to reestablishment of both collective identity and individual self worth. Seemingly in such cases, while hard to quantify, these elements of value system interaction if occurring under globalization could well outweigh conventional Ricardian gains from trade.

It is perhaps worth concluding this section with the comment that similar integrative processes involving the assimilation and mixing of social arrangements now analyzed under globalization, while previously not occurring simultaneously in most countries around the world, characterize large parts of the human historical record. Embree (1972) for instance, discusses how Hindu transitions reflect a long period of assimilation of different cultures and traditions during the Vedic age (1500BC-600BC) 
which fused scattered populations who spoke Dravidian Languages (the modern representatives of Tamil and Telugu), embraced a wide range of different deities, and practiced a wide range of sacrificial and warrior based practices. The fusion produced the golden Vedic age. Many other instances of social clash, assimilation, and inevitable forward movement could be cited.

In this sense value system change under globalization is hardly a new phenomenon or even a new concern. But both the large and central role played by the economic component in modern globalization discussions and the simultaneous reach of globalization into most societies and cultures seems to mark a departure from earlier experiences. If so, this may be a further reason to explore how the theorizing of economists be able to understand better current episodes of globally driven social change. 


\section{Concluding Remarks}

This paper discusses how the many processes of globalization might interact with social value systems and collective identity, and through these interactions how overall societal and economic performance may be impacted. Its thrust is to suggest that economists may be able to contribute to this part of the wider debate on globalization by formalizing simple notions of social value systems (collective identity) and using comparative statics to assess how societal performance might be impacted by globalization shocks. Writings from other disciplines largely document and identify these concerns without using a comparative statics approach.

While at times much maligned by some from other social disciplines, (see Wallerstein’s (2001) call (p.258) “Away with economists” remark), my belief is that working jointly with those from other disciplines, economists can nonetheless make a contribution to debates on how globalization affects social process and how induced societal change affects economic performance by bringing their analytical skills to bear in an interdisciplinary communicatory manner. To think in terms of processes of interaction, competition, cooperation and assimilation between value systems and to more formally develop new analytics and comparative statics of collective rationality beyond the initial ideas set out in this cursory piece is the direction I suggest. Debate on globalization is now centre stage in our emerging global polity, and economists can offer their analytical skills to other disciplines and make important contributions to debate on wider and potentially larger issues than impacts on trade and factor flows. 


\section{$\underline{\text { References }}$}

Akerlof G. (1984), An Economic Theorist's Book of Tales; Cambridge University Press

Arrow K. J. and G. Debreu (1954), “The Existence of a Competitive Equilibrium,” Econometrica.

Arrow K. J. (1970), “The Organization of Economic Activity: Issues Pertinent to the Choice of Market verses Non-Market Allocation” in R. H. Haveman and J. Margolis (ed) Public Expenditure and Policy Analysis, Chicago, Markham

Avineri S. (1978), The Social and Political Thought of Karl Marx; Cambridge University Press.

Bagwell K. and W. Staiger (2003), An Economic Theory of GATT; MIT Press.

Bagwell K. and W. Staiger (2001), “Domestic Politics, National Sovereignty and Economic Institutions,” Quarterly Journal of Economics, vol. 116, pp. 519-562.

Bagwell K. and W. Staiger (1999), “An Economic Theory of GATT,” American Economic Review, vol. 89, pp. 215-248.

Beck U. (1999), World Risk Society; Cambridge : Polity Press ; Malden, MA : Blackwell. Berger P. and T. Luckmann (1967), The Social Construction of Reality: A Treatise in the Sociology of Knowledge; New York, Anchor.

Bhattarai K. and J. Whalley (2004), “Service Trade Liberalization in Networks,” Review of International Economics, forthcoming.

Blau D. (1975), Inequality and Heterogeneity: A Primitive Theory of Social Structure, New York, Free Press.

Blumer H. (1969) Symbolic Interaction: Perspectives and Method; Prentice Hall. 
Burbidge J. B., J. A. DePuter, G. M. Myers, and A. Sengupta (1998), “A CoalitionFormation Approach to Equilibrium Federations and Trading Blocs,” American Economic Review, vol. 87, pp. 940-956.

Castells M. (2004), The Information Age: Economy, Society, and Culture; (3 Volumes), Malden, MA : Blackwell.

Chia N. C. and J. Whalley (1995), “A Numerical Example of Welfare Worsening Liberalizatin of Trade in Banking Services,” Journal of Policy Modelling,

Cicourel A.V. (1973) Cognitive Sociology; Penguin, Harmondsworth.

Coleman J. (1999) “Social Capital in the Creation of Human Capital”, American Journal of Sociology, vol 94, pp. S95-S121

Collier P. (1998), “Social Capital and Poverty,” Social Capital Initiative, working paper No 4, World Bank.

Collins R. (1986), Weberian Sociological Theory; Cambridge; New York : Cambridge University Press.

Comte A. (1876), The Course of Positive Philosophy (3 volumes), London: George Bell Cunningham L. and J. Reich (1984), Culture and Values, $3^{\text {rd }}$ edition, Harcourt Brace. Currie D. and P. Levine (1993), Rules, Reputation, and Macroeconomic Policy Coordination, Cambridge University Press.

Dahrendorf R. (1959) Class and Class Conflict in an Industrial Society; Routhedge, Regent Paul, London

Dawkins R. (1976), The Selfish Gene; Oxford University Press.

Deardorff A. (2003), “What Might Globalization’s Critics Believe?” The World Economy, May, Vol. 26, No. 5, pp. 639-658.

Debreu G. (1959), The Theory of Value, J. Wiley. 
Durlauf S. and M. Falchamps (2004), “Empirical Studies of Social Capital: A Critical Survey” (mimeo).

Durkheim E. (1933), The Division of Labor in Society; New York, Free Press.

Embree A. T. (1972), The Hindu Tradition: Readings in Oriental Thought, Vintage Books.

Ellison G. and D. Fudenberg (1993), “Rules of Thumb for Social Learning”, Journal of Political Economy, vol 101, pp 612-643

Ellison G. and D. Fudenberg (1995), “Word-of-Mouth Communication and Social Learning”, Quarterly Journal of Economics, vol 110, pp 93-125

Ellison G. (1993), “Learning, Local Interaction, and Coordination”, Economica, vol 61, no 5, pp 1047-1071

Garfinkel H. (1967) Studies in Ethnomethodology; Prentice Hall, Englewood Cliffs.

Giddens A. (1973) The Class Structure of Advanced Societies; Hutchinson, London.

Glassner D. (1999), The Culture of Fear; Basic Books.

Granovetter, M. (1985) “Economic Action and Social Structure: The Problem of Embeddedness” American Journal of Sociology, vol 91, no 3, pp. 481-510

Greider, W. (1997), One World, Ready or Not: The ManicLogic of Global Capitalism; New York : Simon \& Schuster.

Hicks J. R. (1939), Value and Capital, Oxford University Press.

Higgott R. (2002), CSGR Working Paper on Globalization as a contested concept; Warwick, UK

Huntington S.P. (1996) The Clash of Civilizations and Remaking of World Order; Simone, Schuster, New York. 
Kanbur R. and M. Keen (1993), “Jeux Sans Frontieres: Tax Competition and Tax Coordination when Countries Differ in Size,” American Economic Review, vol. 83, pp. 877-892.

Kasser T. and V. G. Kasser (2001), “The Dreams of People High and Low in Materialism”, Journal of Economic Psychology, vol. 22, pp 693-719

Kasser T. and A. D. Kanner (ed) (2004) Psychology and Consumer Culture, American Psychological Association, Washington D.C.

Klein N. (2002), No Space, No Choice, No Jobs, No Logo: Taking Aim at the Brand Bullies; New York : Picador USA.

Leibenstein H. (1950), “Bandwagon, Snob, and Weblen Effects in the Theory of Consumer Demand”, Quarterly Journal of Economics, May, pp. 183-207

Lin, Y. (1935), My Country and My People, Foreign Language Teaching and Research Press, Beijing.

Loury G. (1997) “A Dynamic Theory of Racial Income Differences”, in ed. P. Wallace and A. LaMond Women, Minorities, and Employment Discrimination, Lexington Books, Lexington MA

Mathews R. C. O. (1986) “The Economics of Institutions and Sources of Growth,” Economic Journal, vol 96, pp 903-918

Manski C. F. (2002) “Econoic Analysis of Social Interactions”, Journal of Eocnomic Literature, vol 14, no 3, pp. 115-136

Myatt D. P., H. S. Shin and C. Wallace (2002), “The Assessment: Games and Coordination,” Oxford Review of Economic Policy, vol. 18, no. 4, pp. 397-417.

North, D. C (1990), Institutions, Institutional Change and Economic Performance, Cambridge: Cambridge University Press, 1990. 
North, D. C (1997), The Contributions of the New Institutional Economics to an Understanding of the Transition Problem, UNU/Wider 1997 Annual Lecture, Helsinki 1997.

Parsons T. (1937), The Structure of Social Action: A Study in Social Theory with Special Reference to a Group of Recent European Writers; New York, Free Press.

Portes A. (1988), “Social Capital: Its Origins and Applications in Modern Sociology”, Annual Review of Sociology, pp. 1-14

Ritzer G. (2000), The Mcdonaldization of Society, Thousand Oaks, Calif: Pine Forge Press.

Roch P. (1979), The Meaning of Symbolic Interaction; Macmillan, Basingstoke.

Rodrick D. (1997), Has Globalization Gone Too Far?; Institute for International Economics, Washington D.C.

Samuelson P. A. (1947), Foundations of Economic Analysis, Harvard University Press.

Segerstrom, P. (2003) “Naomi Klein and the Anti globalization Movement” in (ed.) M. Lundahl, Globalization and its Enemies, EFI, Economic Research Institute, Stockholm School of Economics.

Siedman S. (2004), Contested Knowledge: Social Theory Today; $3^{\text {rd }}$ Edition, Blackwell. Stiglitz J. (2002), Globalization and its Discontents; New York ; London : W.W. Norton \& Co.

Strange S. (1995), Mad Money; Manchester UK: Manchester University Press.

Veblen T. (1894), The Theory of the Leisure Class

Wallerstein I. (2001), Unthinking Social Science: The Limits of Nineteeth Century Paradigms; Philadelphia: Temple University Press. 
Weber M. (1958), The Protestant Ethic and the Spirit of Capitalism; New York, Free Press.

Weber M. (1951), The Religion of China: Confucianism and Taoism; New York, Free Press.

Whalley J. (2003), Review of Bagwell and Staiger, World Trade Review, forthcoming. Wildasin D. E. (1988), “Nash Equilibria in Models of Fiscal Competition,” Journal of Public Economics,

Williamson O. E. (1998)

Wilson J. D. (1999), “Theories of Tax Competition,” National Tax Journal, vol. LII, No. 2, pp. 269-304.

Wilson E. (1980), Sociobiology; Cambridge, Mass. Belknap Press of Harvard University Press.

Zodrow G. R. and P. Mieszkowski (1986), "Pigou, Tiebout, Property Taxation, and the Underprovision of Local Public Goods,” Journal of Urban Economics, vol. 19, pp. 356-370. 


\section{CESifo Working Paper Series}

(for full list see www.cesifo.de)

1378 Theodore C. Bergstrom and John L. Hartman, Demographics and the Political Sustainability of Pay-as-you-go Social Security, January 2005

1379 Bruno S. Frey and Margit Osterloh, Yes, Managers Should Be Paid Like Bureaucrats, January 2005

1380 Oliver Hülsewig, Eric Mayer and Timo Wollmershäuser, Bank Loan Supply and Monetary Policy Transmission in Germany: An Assessment Based on Matching Impulse Responses, January 2005

1381 Alessandro Balestrino and Umberto Galmarini, On the Redistributive Properties of Presumptive Taxation, January 2005

1382 Christian Gollier, Optimal Illusions and Decisions under Risk, January 2005

1383 Daniel Mejía and Marc St-Pierre, Unequal Opportunities and Human Capital Formation, January 2005

1384 Luis H. R. Alvarez and Erkki Koskela, Optimal Harvesting under Resource Stock and Price Uncertainty, January 2005

1385 Ruslan Lukach, Peter M. Kort and Joseph Plasmans, Optimal R\&D Investment Strategies with Quantity Competition under the Threat of Superior Entry, January 2005

1386 Alfred Greiner, Uwe Koeller and Willi Semmler, Testing Sustainability of German Fiscal Policy. Evidence for the Period 1960 - 2003, January 2005

1387 Gebhard Kirchgässner and Tobias Schulz, Expected Closeness or Mobilisation: Why Do Voters Go to the Polls? Empirical Results for Switzerland, 1981 - 1999, January 2005

1388 Emanuele Bacchiocchi and Alessandro Missale, Managing Debt Stability, January 2005

1389 Assar Lindbeck and Dirk Niepelt, Improving the SGP: Taxes and Delegation rather than Fines, January 2005

1390 James J. Heckman and Dimitriy V. Masterov, Skill Policies for Scotland, January 2005

1391 Emma Galli \& Fabio Padovano, Sustainability and Determinants of Italian Public Deficits before and after Maastricht, January 2005

1392 Angel de la Fuente and Juan Francisco Jimeno, The Private and Fiscal Returns to Schooling and the Effect of Public Policies on Private Incentives to Invest in Education: A General Framework and Some Results for the EU, January 2005 
1393 Juan C. Conesa and Carlos Garriga, Optimal Response to a Demographic Shock, January 2005

1394 Christian Gollier, Optimal Portfolio Management for Individual Pension Plans, February 2005

1395 Ruslan Lukach, Joseph Plasmans and Peter M. Kort, Innovation Strategies in a Competitive Dynamic Setting, February 2005

1396 Gebhard Kirchgässner, (Why) Are Economists Different?, February 2005

1397 Marko Köthenbürger, Panu Poutvaara and Paola Profeta, Why are More Redistributive Social Security Systems Smaller? A Median Voter Approach, February 2005

1398 Gabrielle Demange, Free Choice of Unfunded Systems: A First Assessment, February 2005

1399 Carlos Fonseca Marinheiro, Sustainability of Portuguese Fiscal Policy in Historical Perspective, February 2005

1400 Roel M. W. J. Beetsma and Koen Vermeylen, The Effect of Monetary Unification on Public Debt and its Real Return, February 2005

1401 Frank Asche, Petter Osmundsen and Maria Sandsmark, Is It All Oil?, February 2005

1402 Giacomo Corneo, Media Capture in a Democracy: The Role of Wealth Concentration, February 2005

1403 A. Lans Bovenberg and Thijs Knaap, Ageing, Funded Pensions and the Dutch Economy, February 2005

1404 Thiess Büttner, The Incentive Effect of Fiscal Equalization Transfers on Tax Policy, February 2005

1405 Luisa Fuster, Ayşe İmrohoroğlu and Selahattin İmrohoroğlu, Personal Security Accounts and Mandatory Annuitization in a Dynastic Framework, February 2005

1406 Peter Claeys, Policy Mix and Debt Sustainability: Evidence from Fiscal Policy Rules, February 2005

1407 James M. Malcomson, Supplier Discretion over Provision: Theory and an Application to Medical Care, February 2005

1408 Thorvaldur Gylfason, Interview with Assar Lindbeck, February 2005

1409 Christian Gollier, Some Aspects of the Economics of Catastrophe Risk Insurance, February 2005

1410 Gebhard Kirchgässner, The Weak Rationality Principle in Economics, February 2005 
1411 Carlos José Fonseca Marinheiro, Has the Stability and Growth Pact Stabilised? Evidence from a Panel of 12 European Countries and Some Implications for the Reform of the Pact, February 2005

1412 Petter Osmundsen, Frank Asche, Bård Misund and Klaus Mohn, Valuation of International Oil Companies -The RoACE Era, February 2005

1413 Gil S. Epstein and Shmuel Nitzan, Lobbying and Compromise, February 2005

1414 Marcel F. M. Canoy, Jan C. van Ours and Frederick van der Ploeg, The Economics of Books, February 2005

1415 Eric A. Hanushek and Ludger Wößmann, Does Educational Tracking Affect Performance and Inequality? Differences-in-Differences Evidence across Countries, February 2005

1416 George Kapetanios and M. Hashem Pesaran, Alternative Approaches to Estimation and Inference in Large Multifactor Panels: Small Sample Results with an Application to Modelling of Asset Returns, February 2005

1417 Samuel Mühlemann, Jürg Schweri, Rainer Winkelmann and Stefan C. Wolter, A Structural Model of Demand for Apprentices. February 2005

1418 Giorgio Brunello and Lorenzo Rocco, Educational Standards in Private and Public Schools, February 2005

1419 Alex Bryson, Lorenzo Cappellari and Claudio Lucifora, Why so Unhappy? The Effects of Unionisation on Job Satisfaction, March 2005

1420 Annalisa Luporini, Relative Performance Evaluation in a Multi-Plant Firm, March 2005

1421 Giorgio Bellettini and Carlotta Berti Ceroni, When the Union Hurts the Workers: A Positive Analysis of Immigration Policy, March 2005

1422 Pieter Gautier, Michael Svarer and Coen Teulings, Marriage and the City, March 2005

1423 Ingrid Ott and Stephen J. Turnovsky, Excludable and Non-Excludable Public Inputs: Consequences for Economic Growth, March 2005

1424 Frederick van der Ploeg, Back to Keynes?, March 2005

1425 Stephane Dees, Filippo di Mauro, M. Hashem Pesaran and L. Vanessa Smith, Exploring the International Linkages of the Euro Area: a Global VAR Analysis, March 2005

1426 Hans Pitlik, Friedrich Schneider and Harald Strotmann, Legislative Malapportionment and the Politicization of Germany's Intergovernmental Transfer System, March 2005

1427 Konstantinos Angelopoulos and Apostolis Philippopoulos, The Role of Government in Anti-Social Redistributive Activities, March 2005 
1428 Ansgar Belke and Daniel Gros, Asymmetries in the Trans-Atlantic Monetary Policy Relationship: Does the ECB follow the Fed?, March 2005

1429 Sören Blomquist and Luca Micheletto, Optimal Redistributive Taxation when Government's and Agents' Preferences Differ, March 2005

1430 Olof Åslund and Peter Fredriksson, Ethnic Enclaves and Welfare Cultures - QuasiExperimental Evidence, March 2005

1431 Paul De Grauwe, Roberto Dieci and Marianna Grimaldi, Fundamental and NonFundamental Equilibria in the Foreign Exchange Market. A Behavioural Finance Framework, March 2005

1432 Peter Egger, Stefan Gruber, Mario Larch and Michael Pfaffermayr, Knowledge-Capital Meets New Economic Geography, March 2005

1433 George Economides and Apostolis Philippopoulos, Should Green Governments Give Priority to Environmental Policies over Growth-Enhancing Policies?, March 2005

1434 George W. Evans and Seppo Honkapohja, An Interview with Thomas J. Sargent, March 2005

1435 Helge Berger and Volker Nitsch, Zooming Out: The Trade Effect of the Euro in Historical Perspective, March 2005

1436 Marc-Andreas Muendler, Rational Information Choice in Financial Market Equilibrium, March 2005

1437 Martin Kolmar and Volker Meier, Intra-Generational Externalities and InterGenerational Transfers, March 2005

1438 M. Hashem Pesaran and Takashi Yamagata, Testing Slope Homogeneity in Large Panels, March 2005

1439 Gjermund Nese and Odd Rune Straume, Industry Concentration and Strategic Trade Policy in Successive Oligopoly, April 2005

1440 Tomer Blumkin and Efraim Sadka, A Case for Taxing Education, April 2005

1441 John Whalley, Globalization and Values, April 2005 